\title{
Pre-existing Chronic Kidney Disease, Stage 3
}

National Cancer Institute

\section{Source}

National Cancer Institute. Pre-existing Chronic Kidney Disease, Stage 3. NCI Thesaurus.

Code C150360.

Stage 3 chronic kidney disease that was diagnosed or treated before a specific date. 